This PDF is a selection from an out-of-print volume from the National Bureau of Economic Research

Volume Title: Productivity Trends: Capital and Labor Volume Author/Editor: John W. Kendrick

Volume Publisher: NBER

Volume ISBN: 0-87014-367-0

Volume URL: http://www.nber.org/books/kend56-1

Publication Date: 1956

Chapter Title: Productivity Trends: Capital and Labor

Chapter Author: John Kendrick

Chapter URL: http://www.nber.org/chapters/c5596

Chapter pages in book: (p. -3 - 23) 


\title{
Productivity Trends: Capital and Labor
}

\author{
JOHN W. KENDRICK
}

OCCASIONAL PAPER 53

NATIONAL BUREAU OF ECONOMIC RESEARCH, INC. 1956 


\section{Reprinted from the Review of Economics and Statistics}

Library of Congress catalog card number : 56-9228

PrICE $\$ .50$

The study upon which this paper is based was made possible by funds granted to the National Bureau of Economic Research by the Alfred P. Sloan Foundation, Inc. The Foundation, however, is not to be understood as approving or disapproving by virtue of its grant any of the statements made or views expressed in this publication. 


\title{
NATIONAL BUREAU OF ECONOMIC RESEARCH
}

1956

\author{
OFFICERS
}

Harry Scherman, Chairman

Gottfried Haberler, President

George B. Roberts, Vice-President and Treasurer

W. J. Carson, Executive Director

DIRECTORS AT LARGE

Wallace J. Campbell, Director, Cooperative League of the USA

Solomon Fabricant, New York University

Albert J. Hettinger, Jr., Lazard Frères and Company

Oswald W. Knauth, Beaufort, South Carolina

H. W. Laidler, Executive Director, League for Industrial Democracy

Shepard Morgan, Norfolk, Connecticut

George B. Roberts, Vice-President, The First National City Bank of New York

Beardsley Ruml, New York City

Harry Scherman, Chairman, Book-of-the-Month Club

George Soule, Bennington College

N. I. Stone, Consulting Economist

J. Raymond Walsh, New York City

Joseph H. Willits, Director, The Educational Survey, University of Pennsylvania Leo Wolman, Columbia University

Donald B. Woodward, Vick Chemical Company

Theodore O. Yntema, Vice-President - Finance, Ford Motor Company

DIRECTORS BY UNIVERSITY APPOINTMENT

E. Wight Bakke, Yale

Arthur F. Burns, Columbia

Melvin G. de Chazeau, Cornell

G. A. Elliott, Toronto

Frank W. Fetter, Northwestern

H. M. Groves, Wisconsin
Gottfried Haberler, Harvard Clarence Heer, North Carolina

R. L. Kozelka, Minnesota

C. Arthur Kulp, Pennsylvania T. W. Schultz, Chicago Jacob Viner, Princeton

DIRECTORS APPOINTED BY OTHER ORGANIZATIONS

Percival F. Brundage, American Institute of Accountants

Harold G. Halcrow, American Farm Economic Association

S. H. Ruttenberg, Congress of Industrial Organizations

Murray Shields, American Management Association

Boris Shishkin, American Federation of Labor

Willard L. Thorp, American Economic Association

W. Allen Wallis, American Statistical Association

Harold F. Williamson, Economic History Association

RESEARCH STAFF

Solomon Fabricant, Director of Research

Geoffrey H. Moore, Associate Director of Research

Moses Abramovitz

Morris A. Copeland

David Durand

Milton Friedman

Raymond W. Goldsmith

Millard Hastay

W. Braddock Hickman

Daniel M. Holland

Thor Hultgren
John W. Kendrick Simon Kuznets Clarence D. Long Ruth P. Mack Ilse Mintz

G. Warren Nutter Lawrence H. Seltzer

George J. Stigler Leo Wolman

Herbert B. Woolley 


\section{Relation of The Directors \\ to the Work and Publications \\ of the National Bureau of Economic Research}

1. The object of the National Bureau of Economic Research is to ascertain and to present to the public important economic facts and their interpretation in a scientific and impartial manner. The Board of Directors is charged with the responsibility of ensuring that the work of the National Bureau is carried on in strict conformity with this object.

2. To this end the Board of Directors shall appoint one or more Directors of Research.

3. The Director or Directors of Research shall submit to the members of the Board, or to its Executive Committee, for their formal adoption, all specific proposals concerning researches to be instituted.

4. No report shall be published until the Director or Directors of Research shall have submitted to the Board a summary drawing attention to the character of the data and their utilization in the report, the nature and treatment of the problems involved, the main conclusions and such other information as in their opinion would serve to determine the suitability of the report for publication in accordance with the principles of the National Bureau.

5. A copy of any manuscript proposed for publication shall also be submitted to each member of the Board. For each manuscript to be so submitted a special committee shall be appointed by the President, or at his designation by the Executive Director, consisting of three Directors selected as nearly as may be one from each general division of the Board. The names of the special manuscript committee shall be stated to each Director when the summary and report described in paragraph (4) are sent to him. It shall be the duty of each member of the committee to read the manuscript. If each member of the special committee signifies his approval within thirty days, the manuscript may be published. If each member of the special committee has not signified his approval within thirty days of the transmittal of the report and manuscript, the Director of Research shall then notify each member of the Board, requesting approval or disapproval of publication, and thirty additional days shall be granted for this purpose. The manuscript shall then not be published unless at least a majority of the entire Board and a two-thirds majority of those members of the Board who shall have voted on the proposal within the time fixed for the receipt of votes on the publication proposed shall have approved.

6. No manuscript may be published, though approved by each member of the special committee, until forty-five days have elapsed from the transmittal of the summary and report. The interval is allowed for the receipt of any memorandum of dissent or reservation, together with a brief statement of his reasons, that any member may wish to express; and such memorandum of dissent or reservation shall be published with the manuscript if he so desires. Publication does not, however, imply that each member of the Board has read the manuscript, or that either members of the Board in general, or of the special committee, have passed upon its validity in every detail.

7. A copy of this resolution shall, unless otherwise determined by the Board, be printed in each copy of every National Bureau book.

(Resolution adopted October 25, 1926 and revised February 6, 1999 and February 24, 1941) 


\title{
Productivity Trends: Capital and Labor
}

\author{
John W. Kendrick *
}

$\mathrm{T}$ HIS paper is a summary account of productivity trends since the turn of the century in the American economy, by major segments and industries. Different rates of productivity change in the various industries have significantly altered relative unit costs and prices of products, rates of output, and the distribution of resources by industry. At the national level, productivity growth has been of paramount importance in raising levels of living, in strengthening potential national security, and in the provision for future economic growth.

Differences among nations in levels and rates of change in productivity are fundamental measures of comparative economic performance and play a crucial role in the competition among nations and groups of nations. The more we can learn of economic growth generally, and of productivity changes in particular, the better equipped we are to survive the competition and to enjoy continued advances in our planes of living.

* This is the first article published by this Revrew in collaboration with the National Bureau of Economic Research We expect to continue this collaboration. This paper is a summary of part of a larger study of productivity trends in the United States in preparation for the National Bureau. The author is indebted to Moses Abramovitz and Thor Hultgren of the Bureau staff for helpful criticism; Maude R. Pech has assisted greatly throughout in preparing the underlying estimates, a full description of which will appear in the later monograph.

The present paper has been approved for publication, as a report of the National Bureau of Economic Research, by the Director of Research and the Board of Directors of the National Bureau, in accordance with the resolution of the Board governing National Bureau reports (see the 36th Annual Report of the National Bureau of Economic Research, May 1956). It is to be reprinted as No. 53 in the National Bureau's series of Occasional Papers. 


\section{Method and Meaning}

It will be helpful in understanding the following summary and analysis of our quantitative findings to date to consider briefly the concept of productivity, the methods used to derive the estimates, and the meaning of changes in productivity as measured. Productivity can also be compared as between producing units or complexes turning out similar products, but the focus of this paper is on temporal comparisons.

Concept. The term "productivity" is frequently used loosely to denote the ratio of output to any related input or class of inputs. In this sense, there is a spectrum of productivity ratios, each of which indicates the savings achieved in particular cost elements over time as a result of changes in productive efficiency and factor substitutions. In order to attempt to measure changes in productive efficiency as such, however, output must be related to the aggregate of corresponding inputs. This is so because the proportions in which factors are combined usually change over time because of changes in relative factor prices or in technical knowledge.

When proportions have varied, changes in the ratio of output to one input or class of inputs reflect inter-factor substitution as well as changes in over-all productive efficiency. This is the chief objection to output per manhour as an indicator of productivity change. Only by relating output to all tangible inputs can it be determined whether there has been a net saving in real costs per unit of output, or conversely, a gain in productivity. Increasingly since World War II, attempts have been made to measure "total factor productivity," ${ }^{1}$ but the work un-

${ }^{1}$ The movement to measure productivity in terms of all relevant inputs was keynoted by Hiram S. Davis at the first National Conference on Productivity held in Washing- 
derlying this paper represents the broadest effort in that direction to date.

Sources and methods. For 33 industry groups and the private domestic economy as a whole, we have estimated total factor productivity as well as the ratios of output to each of the two broad factor classes: labor and capital (including natural resources). For the distribution segment and for 80 manufacturing industries, we have estimated the ratio of output to labor input alone, since capital data were lacking. The estimates, which generally cover the period I899-I953, have been made possible by the pioneering studies of output, employment, and capital by the National Bureau of Economic Research, supplemented and brought up to date by the author, using basically the same methods. $^{2}$ The estimates are still preliminary and subject to review before publication.

For strict comparability with the basic fac-

ton in 1946 (see Summary of Proceedings of Conference on Productivity, Dept. of Labor, Bull. 913, 1946, p. II). A recent book by Davis describes the concept and methodology for measuring composite productivity at the level of the firm (Hiram S. Davis, Productivity Accounting, Research Studies XXXVII, Wharton School of Finance and Commerce, University of Pennsylvania, Philadelphia, 1955). See also G. T. Barton and M. R. Cooper, "The Relation of Agricultural Production to Inputs," this REview, XXX (May 1948), II 7-26; Jacob Schmookler, "The Changing Efficiency of the American Economy, I869-I 938," this REvIEw, XXXIV (August I952), 2I4-3I; George J. Stigler, Trends in Output and Employment (National Bureau of Economic Research, New York, I947); Solomon Fabricant, "Economic Progress and Economic Change," Thirty-fourth Annual Report, National Bureau of Economic Research (1954).

${ }^{3}$ The relevant industry studies, published by the $\mathrm{Na}$ tional Bureau of Economic Research, New York, are: Solomon Fabricant, The Output of Manufacturing Industries, r899-1937 (1940), and Employment in Manufacturing, 1899-1939: An Analysis of Its Relation to the Volume of Production (1942); Harold Barger and Sam S. Schurr, The Mining Industries, 1899-1939: A Study of Output, Employment and Productivity (1944); Jacob Martin Gould, Output and Productivity in the Electric and Gas Utilities, r899-1942 (1946); Harold Barger, The Transportation In- 
tors of production, output should be estimated net of intermediate products consumed in the process of production. Our estimates of real private domestic product are net in this sense. Of the industry output estimates, only those for the farm segment are net, representing the real value added to materials and services purchased from other industries. The nonfarm industry output figures are gross and are fully consistent with the national product estimates only on the assumption that the ratio of net to gross has not changed significantly. There are some indications that net output has risen secularly relative to gross in the nonfarm economy; to that extent our productivity estimates in that area have some downward bias. ${ }^{3}$

dustries, 1899-1946: A Study of Output, Employment, and Productivity (r95 I), and Distribution's Place in the American Economy since 1869 (1955); Daniel Creamer, Capital and Output Trends in Manufacturing Industries, r8801948, Occasional Paper 4I (I954); Melville J. Ulmer, Trends and Cycles in Capital Formation by United States Railroads, I870-1950, Occasional Paper 43 (r954); Alvin S. Tostlebe, The Growth of Physical Capital in Agriculture, I870-1950, Occasional Paper 44 (1954); Israel Borenstein, Capital and Output Trends in Mining Industries, I870-I948, Occasional Paper 45 (1954). Some unpublished National Bureau materials were also utilized. Estimates of real farm product are those published by the Department of Commerce; employment and manhours worked on farms are the estimates of the Department of Agriculture.

The real private domestic product estimates are based on Department of Commerce estimates, extrapolated for years before $I 929$ by major expenditure segments, using estimates by Simon Kuznets for personal consumption and private investment, and estimates by the author for government purchases of goods and services. The estimates of real net productive assets are largely those of Raymond Goldsmith. The economy manhour estimates are the sum of industry manhour estimates mentioned above, supplemented by the author. The relative weights for labor and capital inputs in the base year 1929 are based on the Department of Commerce national income estimates, with an imputation of labor reward to entrepreneurs based on the average compensation of employees in the various industries.

${ }^{3}$ For comparison of a weighted aggregate of gross industry output indexes with an index of the corresponding segment of real private domestic product, see the paper prepared by the author for the November 1955 Conference 
Output measures do not, of course, reflect improvements in the quality of given products. If the degree of quality change differs over time and between industries, then temporal and interindustry comparisons of output and productivity are affected in a possibly serious way. Quality improvements due to a changed product-mix are reflected in the indexes to the extent that units are measured in terms of detailed types of products. That is, a relative shift in production from a lower to a higher value type of good within a given product class shows up as a rise in total real output if the units of the various product types are measured and weighted separately. The same result is obtained by the deflation of value estimates by appropriate price indexes. Various other qualifications attach to output measures, but these are generally well known and need no amplification here.

Our measures of factor inputs in real terms are taken net of changes in productive efficiency. This is in contrast to the current value estimates of factor income, which include the income, i.e., the share of product, arising from increasing efficiency. By weighting the real input units by their base period prices - which approximate their marginal contribution to output in that period - we obtain measures of what the inputs of a given period would have produced had their productive efficiency per unit remained the same as in the base period. The ratio of these inputs of standardized efficiency to the actual output of the given period, at base period prices, yields the index of change in productive efficiency.

Specifically, the labor input measure is based

on Research in Income and Wealth, "Comments on the Estimation of Real National Product" (National Bureau of Economic Research, 1955, mimeographed), I7-18. This paper contains a much more detailed critique of output indexes than can be given here. 
on estimates of manhours worked in the various industries by all types of persons engaged in productive activity (including proprietors), weighted by base period average hourly earnings. The manhour is not a fully constant unit in terms of services produced within a given technological framework, but it is the closest approximation available.

Real capital input is measured by the constant dollar value of the stock of real capital land, plant, equipment, and inventories - employed in the several sectors, weighted by base period rates of return. This procedure implies that capital services move proportionally with capital stocks. In the case of plant and equipment, a measure of net stock, after depreciation allowances, fits our conceptual framework better than available alternatives. As nonpermanent assets age, their contribution to net output declines; this is the result of declining gross output capacity, increasing maintenance and repair costs, and creeping obsolescence. Obsolescence results in the reduction of the rate of return on old equipment not only when the installation of new equipment leads to reduced product prices or higher factor prices, but also when the old equipment is utilized less intensively or in less productive activities. Empirical and theoretical considerations suggest that these effects may be assumed to occur gradually over the lifetime of groups of capital items. ${ }^{4}$

Fortunately for our purpose, the price deflators for plant and equipment do not make allowance for changes in efficiency of the capital items, only for changes in real cost of the items when specifications are changed. The deflated value of capital stock thus represents what it would have cost in the base year to produce the given year stock. Since quality changes are not taken into account, the associated capi-

- See particularly George Terborgh, Realistic Depreciation Policy (Washington, 1954). 
tali input measures what the real services of the stock would have been had base period technology prevailed in all periods and if changes in scale were neutral in their effect on output-input ratios.

Meaning of productivity change. Total factor productivity is affected not only by technical change or innovation - reflecting advanced know-how as brought to bear by the entrepreneur on production processes; it is also influenced by variations in the rate or scale of production. We have tried to abstract from variations in the rate of production (relative to capacity) by comparing productivity in years of high economic activity. The secular movements in productivity over the subperiods and the period as a whole may therefore be interpreted as reflecting chiefly the effect of technical innovation and changes in scale of output. By the latter, we mean the net outcome of tendencies toward increasing and diminishing returns that arise because certain productive agents need not be expanded proportionally with output, while others cannot be. Under technical change, we would include both autonomous innovations and those induced by changes in scale.

Finally, it should be made explicit that by measuring inputs in terms of their base period efficiency, we are neglecting changes per factor unit in the services of immaterial capital accumulated in order to increase the efficiency of resources in future periods. This "cultural" capital is largely the technical knowledge of individuals, accumulated by investment in education and research, and its services are manifested through the application of technical know-how by individuals directly in productive activity, or through the instruments of production. Since measurement of changes per factor unit in the real services of intangible capital 
would have to be approached in terms of the savings in real costs achieved by the application of greater productive knowledge, the productivity index itself is the necessary first approximation to measurement of the "missing" factor.

Insofar as interindustry differentials in factor remuneration reflect differences in intangible capital and its services per unit of input, relative shifts of factors toward higher paying industries result in an increased real input associated with the intangible investment required to adapt factors to more productive uses. To this extent, our aggregate input estimates do reflect increasing quality of inputs as a result of changing input mix - but not improvement in the quality of resources within the several industry groups whose inputs are separately weighted. ${ }^{3}$

\section{Long Period Rates of Change, 1899-1953}

Between the years 1899 and 1953 , total factor productivity in the private domestic economy rose at an average annual rate of $13 / 4$ per cent. Productivity gains thus accounted for more than half of the 3.3 per cent average rate of growth in real product.

A weighted average of productivity indexes in the industry groups for which we have esti-

\footnotetext{
${ }^{B}$ Regardless of the source of industry differentials in resource remuneration, a changing composition of inputs affects movements in real output as well as in real input. Thus internal weighting of each eliminates the effect of interindustry shifts, and changes in the productivity ratio are thereby reduced to a weighted average of changes in productive efficiency within the various industries. Another advantage of internal weighting is that the resulting productivity measure indicates the rate of increase in unit compensation of the factors which is consistent with stable product prices. That is, part of the increase in real output relative to unweighted input accrues to the factors as a result of upgrading; by including this with input, changes in the resulting productivity measure indicate the changes in real factor compensation due to improved efficiency of the factors within given uses.
} 
mates shows a 2.0 per cent average annual rate of gain (see Table I below). Within the covered area, the manufacturing and mining segments each show a productivity gain of 2 per cent, the average rate for the whole area. A less than I per cent increase in agriculture is offset by productivity gains in transportation and public utilities well above average.

Table 1. - Average Annual Rates of Gain in Productivity Ratios, Private Domestic Economy and AgGregate OF 33 INDUSTRY GROUPS

(Per cents)

\begin{tabular}{lccc}
\hline \hline & \multicolumn{3}{c}{ Output per unit of } \\
\cline { 2 - 4 } & $\begin{array}{c}\text { Total } \\
\text { input }\end{array}$ & $\begin{array}{c}\text { Labor } \\
\text { input }\end{array}$ & $\begin{array}{c}\text { Capital } \\
\text { input }\end{array}$ \\
\hline Private domestic economy & I.7 & I.9 & I.I \\
Aggregate of industry groups: & & & \\
$\quad$ Weighted & 2.0 & 2.4 & I.3 \\
Unweighted & 2.3 & 2.6 & I.4 \\
\hline \hline
\end{tabular}

The difference between the rates of growth in productivity in the economy as a whole and in the industrial sector covered by this study implies that productivity in the uncovered segments - trade, service, finance, and construction, which account for almost half of national product - increased at an average rate of less than $I / 2$ per cent a year. This figure should not be interpreted as a precise estimate because the deflators for the service industry products included in the national product leave much to be desired. It is, rather, some evidence of the plausibility of our estimates of productivity in the private domestic economy - supported by the specific evidence supplied by Barger that output per manhour in trade has risen signifcantly less than that in commodity-producing industries. $^{\circ}$

The 33 industry groups show no negative productivity changes over the long period; the

- See Harold Barger, Distribution's Place in the American Economy since 1869 . 
average annual rates of gain range from 0.6 per cent in bituminous coal mining to 5.3 per cent in electric utilities. The changes are concentrated in the I to 3 per cent class intervals; the frequency distribution is somewhat skewed to the right (shown in the first colum of Table 5 ). Essentially the same picture of dispersion emerges for the 80 manufacturing industries with respect to output per manhour.

In the private domestic economy and in the covered groups as a whole, output per unit of labor input increased considerably faster than output per unit of capital input (see Table I). This reflects an increase in capital per unit of labor input - by 0.8 per cent a year in the economy as a whole, on average. Since, however, the weight of the capital input index is .28 compared with a .72 weight for the labor input index, our measure of the substitution of capital for labor (total input divided by labor input) shows an average rate of increase of about one-fourth of one per cent a year.

In all of the industry groups but two, capital input increased more than labor input. The index of substitution of capital for labor increased at an average annual rate of between 0.1 and 0.3 per cent for more than half of the groups. Thus factor substitution has not been a major element in labor-saving in most groups; and while indexes of output per manhour show somewhat higher rates of growth than total factor productivity indexes, the relative positions of industries are much the same by both measures. In several groups, however, the substitution of capital for labor exceeded I per cent a year, on average - notably in tobacco manufactures, petroleum refining, crude oil and gas production, and natural gas utilities. These are also groups in which productivity gains exceeded the economy average.

Despite the greater increase in capital than in 
labor inputs, output per unit of capital has generally risen over the long period. Innovation has therefore been capital-saving as well as labor-saving, on the whole. In the few groups that are exceptional in this respect, the growth of capital has only slightly exceeded the growth of output. The almost universal gains in productive efficiency may thus be regarded as established irrespective of the weighting system employed in combining the factor inputs in the various industry groups.

It is of economic significance that the dispersion of changes in total factor productivity is less than that in either of the partial outputinput ratios in the 33 groups. This is revealed by the average deviations shown in Table 4 below. The smaller degree of dispersion of group changes in total factor productivity is due to a significant positive correlation between relative changes in capital (and total input) per unit of labor input and in output per unit of labor input. ${ }^{7}$ To state it differently, there is a negative regression between the deviations from their means of changes in the two partial output-input ratios: relatively small (large) increases in output per unit of capital tend to be associated with relatively large (small) increases in output per manhour.

\section{Subperiod Rates of Change}

In speaking of "average annual rates of change" in the preceding section, we have not meant to suggest that productivity grows at an even pace from year to year, or even from decade to decade. Variations in annual percentage changes are large: in the private domestic econ-

\footnotetext{
${ }^{7}$ The coefficient of rank correlation between per cent changes 1899-1953 in capital per unit of labor input and output per unit of labor input is +.38 . The coefficient is +.51 when the correlation is based on per cent changes in total input per unit of labor input and output per unit of labor input.
} 
omy, the average deviation exceeds the average annual per cent change in each of the 3 ratios. $^{8}$ Average annual rates of change between years of high-level business activity approximately a decade apart (which we call "subperiods") are much more stable than annual changes but still show considerable variability.

Temporal variability. In general, the greater the degree of industry disaggregation, the greater the variability among subperiods in rates of change in the ratios. As Table 2 shows, the variability is greater for the 33-group aggregate than it is for the private domestic economy as a whole; the average variability of subperiod rates of change in the group ratios is approximately twice as great as it is with respect to the same ratios for the group aggregate. Although the table covers only the manufacturing segment, it is true for all segments that variability in rates of change over time is greater in the

Table 2. - Average Deviations of Subperiod Rates of Change in Total factor Productivity and in Partial Output-Input Ratios from the LongPeriod Rates of Change, i 899 to 1953

(Average annual per cent rates)

\begin{tabular}{|c|c|c|c|}
\hline & $\begin{array}{c}\text { Total } \\
\text { factor pro- } \\
\text { ductivity }\end{array}$ & $\begin{array}{l}\text { Output pe } \\
\text { unit of } \\
\text { labor } \\
\text { input }\end{array}$ & $\begin{array}{l}\text { Dutput per } \\
\text { unit of } \\
\text { capital } \\
\text { input }\end{array}$ \\
\hline Private domestic economy & 0.5 & 0.5 & 0.9 \\
\hline Aggregate of 33 groups & 0.8 & 0.9 & $\mathrm{I} .2$ \\
\hline Average of 33 groups & I.6 & 1.7 & 2.1 \\
\hline Manufacturing segment & I. 4 & I .4 & 2.0 \\
\hline Average of 20 groups & I.8 & 1.8 & 2.3 \\
\hline Average of 80 industries & & $2 . I$ & \\
\hline
\end{tabular}

${ }^{8}$ The pertinent calculations for the private domestic economy, r899-1953, are as follows:

Average of annual

\begin{tabular}{ccc} 
Total & \multicolumn{2}{c}{ Output per unit of: } \\
\cline { 2 - 3 } input & $\begin{array}{c}\text { Labor } \\
\text { input }\end{array}$ & $\begin{array}{c}\text { Capital } \\
\text { input }\end{array}$ \\
I.8 & 2.0 & I.2 \\
2.4 & 2.6 & 2.9
\end{tabular}

Average deviation

'The subperiods selected for comparison purposes are: I899-1909; I909-I9; I919-29; I929-37; 1937-48; and I94853 . 
component groups or industries, on average, than for each of the segment aggregates.

It can also be seen from the table that the rate of change in total factor productivity varies less over time than the average rates of change of the two partial output-input ratios. The tendency is more pronounced for the 33 groups than it is for the total economy and the manufacturing segment alone, but it holds for all comparisons. This suggests that among subperiods, as well as among industries, relative changes in capital per manhour are positively correlated with relative changes in output per manhour. ${ }^{10}$ Here, again, relatively high rates of substitution of capital for labor are associated with relatively high rates of increase in output per manhour and with relatively low rates of change in output per unit of capital input.

Patterns of change. Next, let us inquire whether the rates of change in productivity have any systematic relationship to time. Each group shows a somewhat different pattern of movement in productivity over time - reflecting still different patterns in the component industries. But taking either the productivity ratios for the economy as a whole, or for the 33-group aggregate, one striking fact stands out: there has been a significant acceleration of productivity advance since the end of World War I as compared with the prior two decades. The acceleration is most pronounced in the output-capital ratio, but it is also unmistakable in the output-labor ratio. (See Table 3.)

${ }^{10}$ This implies a positive relationship between relative changes in total factor input per unit of labor input and in output per unit of labor input in the subperiods - which in fact obtains in all subperiods except one. The coefficients of rank correlation are:

$\begin{array}{llll}1899-1909 & +.45 & 1929-37 & +.41 \\ 1909-19 & +.61 & 1937-48 & -.02 \\ 1919-29 & +.46 & 1948-53 & +.49\end{array}$


Table 3. - Average Annual Percentage Rates of Change, Total factor Productivity and the Partial Output-Input Ratios, Selected Periods

(Per cents)

\begin{tabular}{|c|c|c|c|}
\hline & $\begin{array}{l}1899- \\
1953 \\
\end{array}$ & $\begin{array}{l}1899- \\
1919\end{array}$ & $\begin{array}{l}1919- \\
1953\end{array}$ \\
\hline \multicolumn{4}{|l|}{ Total factor productivity } \\
\hline $\begin{array}{l}\text { Private domestic economy } \\
\text { Covered sector } 33 \text {-group ag- }\end{array}$ & I.7 & I.I & 2.2 \\
\hline gregate) & 2.3 & I.4 & 2.9 \\
\hline \multicolumn{4}{|l|}{ Output-labor ratio } \\
\hline Private domestic economy & I.9 & I.4 & 2.3 \\
\hline Covered sector & 2.6 & 1.8 & 3.2 \\
\hline \multicolumn{4}{|l|}{ Output-capital ratio } \\
\hline Private domestic economy & I.I & 0.2 & I.7 \\
\hline Covered sector & I.4 & -0.2 & 2.3 \\
\hline
\end{tabular}

There does not appear to have been either further acceleration, or retardation, in the primary trend rate of increase in total factor productivity since I9Ig. A straight line passed through the logarithms of the total factor productivity estimates for the years 1919 and 1953 passes through the estimates for 1929, 1940$4 \mathrm{I}$, and closely hugs the estimates for the years I950-53. Alternative methods of fitting a trend-line yield approximately the same result. The line we have described passes above the estimates for the years 1937 and 1948 ; this is explainable in terms of the less than full cyclical recovery in the earlier year, and the still incomplete postwar readjustment in I948. Thus the rate of productivity change since 1948 , on the surface, suggests some acceleration in productivity growth in the private economy since World War II, but this is a function of a comparison base which lies below the primary trend. Productivity in the 33-group aggregate actually shows a smaller rate of increase I 948-53 than the average rate from I9I9 to 1948 - which suggests that there has been some acceleration in the rate of productivity gain in the uncovered service and construction areas. It would 
be most interesting, if true, that the previously lagging sectors are catching up, but we cannot regard this as an established fact without more reliable, direct estimates. Output per manhour in the trade segment, estimated by the Barger method, has increased considerably faster since I 948 than the trend rate.

Dispersion of changes in subperiods. In the several subperiods, the dispersion of industry group changes in productivity and the partial ratios is about twice as great, on the average, as it is over the long period. This is also true of output per manhour in the 80 manufacturing industries. (See Table 4.) The table also shows that the dispersion of group changes in total factor productivity is less than that for the partial ratios in the subperiods. This tendency holds for each of the subperiods as well as on average.

TABLE 4.-Dispersion OF Group and IndUStry Changes in Productivity, Average of Subperiods vs. Period, I899-1953"

(Per cents)

\begin{tabular}{|c|c|c|c|}
\hline & \multirow{2}{*}{$\begin{array}{l}\text { Average } \\
\text { annual } \\
\text { rate of } \\
\text { change }\end{array}$} & \multicolumn{2}{|c|}{$\begin{array}{l}\text { Average deviations of } \\
\text { industry rates of } \\
\text { change from rate } \\
\text { for aggregate }\end{array}$} \\
\hline & & $\begin{array}{c}\text { Long } \\
\text { period, } \\
\text { r89-1953 }\end{array}$ & $\begin{array}{l}\text { Average of } \\
\text { subperiods }\end{array}$ \\
\hline \multicolumn{4}{|l|}{33 industry groups } \\
\hline Total productivity & 2.3 & 0.8 & I.5 \\
\hline Output-labor ratio & 2.6 & 0.9 & 1.7 \\
\hline Output-capital ratio & I.4 & I.0 & 2.1 \\
\hline \multicolumn{4}{|c|}{80 manufacturing industries } \\
\hline Output-labor ratio & 2.1 & 0.9 & $2 . I$ \\
\hline
\end{tabular}

- For the manufacturing industries, the period is $1899-1947$, with five component subperiods instead of the six into which the period r89-1953 is divided.

The greater dispersion of productivity changes in the subperiods relative to the long periods can be seen more graphically in the frequency distributions (Table 5). While there 
were no negative changes over the long period in total factor productivity and in output per manhour in the groups, there are a few negative changes in each of the subperiods. The majority of groups exhibit continuous productivity growth over all subperiods; the other groups show interruptions to growth in one, and in a few cases two, subperiods. A larger number of negative changes in the subperiods appear in the output-capital ratio. In the first two decades of the century, the declines predominate. Before IgIg, the capital coefficients in most manufacturing and mining industries were rising; i.e., the output-capital ratios were falling. This was approximately offset in its effect on the economy by a rise in the output-capital ratios in most of the regulated industries which had gone through a period of building up plant and falling output-capital ratios in earlier decades. After World War I, the ratios rose in most manufacturing and mining industries as well as in other segments of the economy, although the continuity of advance still was less than in output per manhour and total productivity.

Relative position of industries. Rates of productivity change in given industries have fluctuated markedly in successive subperiods, not only in percentage terms but also in relation to the rates of change in other industries. This is implied by the previous analysis. It is confirmed by a ranking of the various industries and industry groups with respect to change in the output-input ratios in each subperiod and the period as a whole. We ranked the industry group with the smallest gain in productivity as $I$ and that with the largest gain as 33. The manufacturing industry with the least gain was also ranked as I and that with the largest as 80 . The ranks in the subperiods for most of the groups and industries were found to deviate 


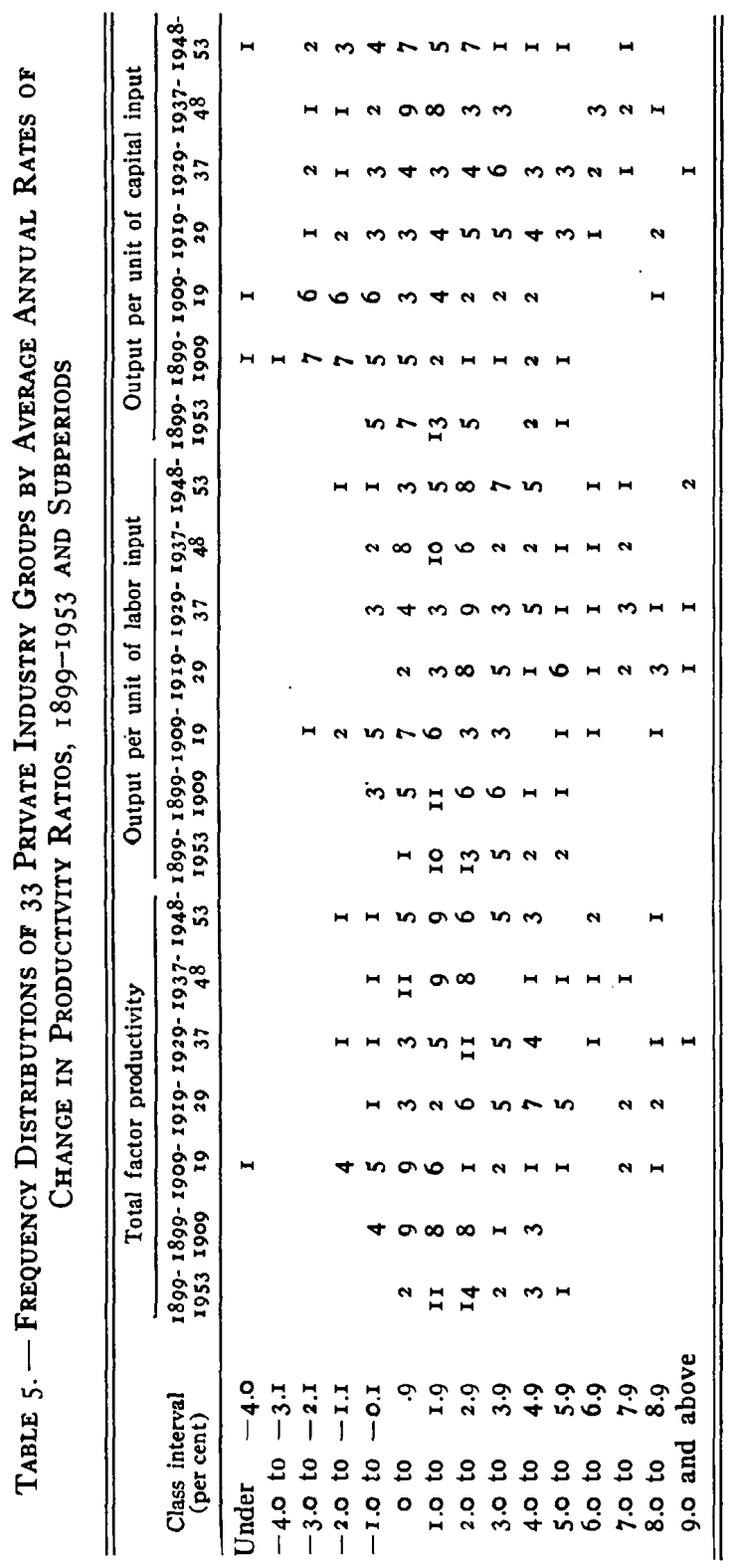




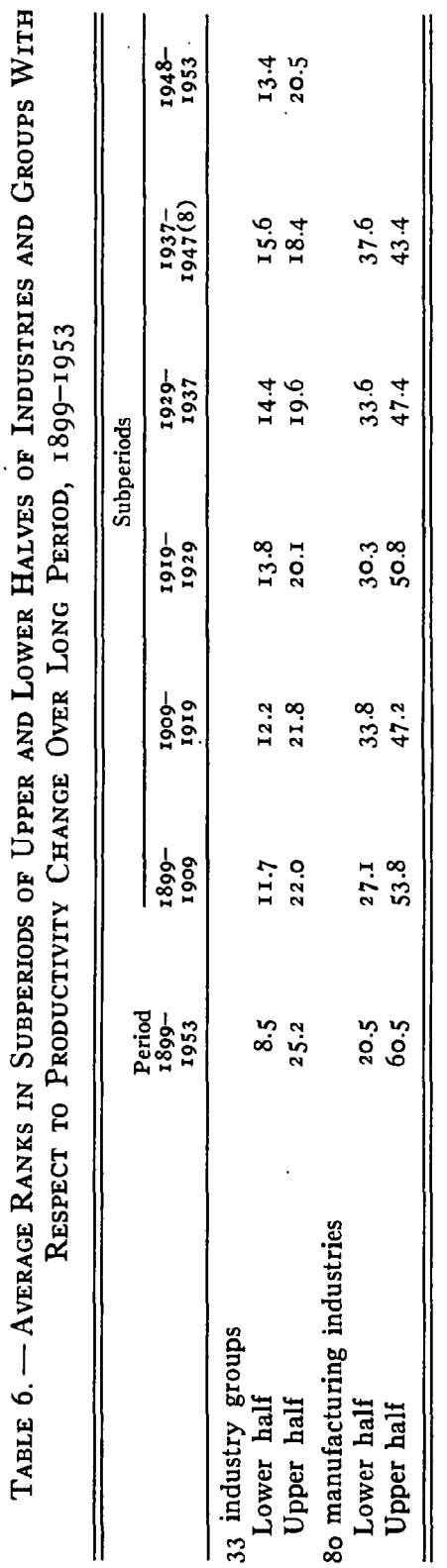


markedly from their average rank over all the subperiods. ${ }^{11}$

There is a tendency, apparent in Table 6, for groups and industries with low rank for the period as a whole to improve their relative standing over time, and for those with high rank to slip somewhat. The prevalence of the tendency over all subperiods except one, in each set of industries, suggests that it is a real phenomenon. The basis of the tendency could be an acceleration in the diffusion of innovation over the period. This is consistent with evidence of a downward trend in the measures of dispersion of productivity change among industries over the subperiods, although the trend is not sufficiently pronounced to be conclusive.

\section{Some Implications of the Productivity Ratios}

The process of technical advance. We have seen that there are no industry groups, and few industries, with negative productivity change over the long period; in fact, group and industry rates of productivity gain are rather heavily concentrated about their means. These facts attest to the strength and breadth of the forces promoting technological advance and increasing returns in our economy, and the diffusion of

${ }^{11}$ The averages of the subperiod ranks of the 33 groups with respect to total factor productivity range from 8 to 27. The mean average deviation of subperiod ranks is 7.0 , as compared with a maximum possible mean average deviation of 8.25. The mean average deviation of subperiod ranks from average ranks for the period as a whole with respect to output per manhour in the manufacturing industries is 17.5 ; this compares with a maximum possible mean average deviation of 20.0 .

The variability of rank explains the fact that in Table 6 the average rank of the lower (higher) half of the groups or industries over the period as a whole is lower (higher) than the average rank of the same industries in the subperiods. This is a consequence of the fact that some of the groups and industries that fall into one of the halves with respect to change over the long period cross into the other half in one or more of the subperiods. 
basic innovations throughout the various industries.

The basic force behind innovation and its spread has been, of course, competition among firms for markets and profits. Firms that lag for long behind their competitors in reducing unit real costs cannot survive. In our age, this means that management must be creative, or at least ready to avail itself of developments initiated elsewhere. In many lines, investment in research and development activity is essential.

Our analysis of industry changes in productivity over successive short periods indicates that the rate of technical advance varies greatly from one industry to another. Other things being equal, it is to be expected that important inventions and innovations will occur in more or less random fashion among industries in the subperiods. Other things are not wholly equal, of course, and a possibly fruitful line of research would be to investigate the relationship between relative changes in productivity and relative changes or differences among industries in causal factors such as investment policy (including research and development) and the related factor of financial resources, the degree of competition, and other facets of industry structure. Nevertheless, it is probable that only part of interindustry differentials in productivity gain could be explained, and part would remain ascribable to random influences. ${ }^{12}$

${ }^{1 s}$ Although we speak of the productivity of an industry or industrial group, it is clear that this does not imply an unqualified attribution of credit to the factors employed within the industry for the productivity gains. Insofar as economies of scale are experienced as a result of the over-all growth of the economy, working through the income elasticity of demand or through shifts in demand curves, the individual industry is hardly responsible. Greater credit may be given if through more rapid technical progress and relative price declines, an industry's share of the market increases and economies of scale result. Even with regard to technical progress, while the management of firms in an 
Possibly more important is the fact that many fundamental innovations, while pioneered in certain industries, have broad applicability in other industrial areas. Examples of such "linked innovations" 13 are the various sources of power, automatic controls, materials handling equipment, office machinery, or management techniques. It seems reasonable to believe that linked innovations spread across industry lines with a considerable lag. Pioneering firms may be imitated more promptly by other firms in the same industry than by firms in other industries, since communication may be greater, less adaptation necessary, and immediate competitive pressures stronger. When the innovation is taking hold in other industries, the rate of development may be slowing down in the initiating industry, which results in a drop in its relative standing, at least temporarily.

Incidence of increased returns. It is common knowledge that industries have shared unequally in the expanding national market. There is a significant correlation between relative changes in output and relative changes in total productivity. For the industry groups, the coefficient of rank correlation is +.65 ; the coefficient is virtually the same when per cent changes in output are related to per cent changes in output per manhour in the industry groups $1899-1953$, and in the manufacturing industries $1899-1947$. To a lesser degree, relative changes in output and productivity are positively correlated in the subperiods.

This positive relation between output and

industry may be credited with the requisite initiative, frequently the inventions and initial innovations originate outside a given firm or industry and spread by imitation, as we have remarked.

${ }^{13}$ See B. S. Keirstead, The Theory of Economic Change (Toronto, I948), ch. VIII. 
productivity should not be construed as reflecting solely the influence of increasing returns to scale. The relationship involves mutual interaction. Relative changes in output are partly a function of relative price changes which, in turn, tend to reflect relative changes in productivity. In the 80 manufacturing industries, the coefficient of rank correlation between relative changes in output per manhour and price from I 899 to 1947 is $-.69 .{ }^{14}$ Since productivity change is in part a result of autonomous innovation, the associated changes in price and output are also in part a result of the same factor, and the interrelation between output and productivity can only in part be attributed to economies of scale. It does not appear to be feasible to measure separately the portion of productivity change resulting from economies of scale.

Implications for projection. As superior measures of change in productive efficiency vis-à-vis the conventional output per manhour ratios, total productivity indexes should yield more meaningful results in the analysis and projection of productivity change and its relationship to other variables.

Given output, total productivity explains and makes possible the projection of factor input requirements, in total and individually, in terms of the dual forces of change in productive efficiency and factor substitutions. Given

"A high degree of correlation between relative changes in productivity and product prices implies a low degree of correlation between relative changes in productivity and factor prices. The coefficient of rank correlation between relative changes in output per manhour and average hourly earnings, $1899-1947$, is .20 . It is interesting that the average coefficient of correlation between the two variables in the several subperiods is .35 ; this is consistent with an average coefficient of correlation between relative changes in output per manhour and price in the subperiods of -.55 compared with the -.69 obtained in the correlation of the variables for the period as a whole. 
factor prices, total productivity makes possible the explanation and projection of a consistent set of product prices.

The most frequent use of output-input ratios in forecasting has been to build output projections based on projections of input and productivity. The productivity projection is usually based on historical trends. Since changes in total factor productivity have shown less dispersion by industry and less variability over time than output per manhour, projections of total productivity should be subject to a smaller error. Moreover, use of total productivity requires the forecaster to make explicit assumptions as to the movements of capital stock. This requires integration with his capital formation and saving projections, which have usually not been related explicitly to projected changes in productivity, but which are relevant.

Whether output projections are based on total factor productivity or on output per manhour, our analysis confirms the wisdom of making the projection in terms of macro-economic variables. A breakdown of output for a target year by type of product and industrial origin, in order to make supposedly more refined successive approximations to the output forecast by means of industry productivity projections, has some theoretical appeal. But since industry rates of change are much more variable than those for segments and the economy as a whole, it is probable that more would be lost by attempted refinement than would be gained. 